\title{
Stabilization of Disintegrating Ferroalloy and Steelmaking Slags
}

\author{
B.L. Demin', Yu.V. Sorokin¹, L.A. Smirnov ${ }^{1,2}$, and Ye.N. Shcherbakov ${ }^{1}$ \\ ${ }^{1}$ Ural Institute of Metals JSC, Yekaterinburg, Russia \\ ${ }^{2}$ Federal Publicly Funded Institution of Science Institute of Metallurgy of Ural Branch of the \\ Russian Academy of Sciences, Yekaterinburg, Russia
}

\section{Abstract}

High-basic refinery slags are susceptible to silicate disintegration and turn into powder at cooling, and it is the cause of a negative impact of slag disintegration products on the environment. An applied method of slag disintegration preventing is the stabilization of its structure in the process of formation or cooling. The crystallographic method of stabilization of disintegrating slags lies in introducing micro additives into the slag composition. To realize the thermal method of slag stabilization, a rotor-type installation with a ball piece is proposed. Approbation of the applied methods of disintegrating slag stabilization showed their efficiency for producing a material with a number of new

Received: 5 February 2019

Accepted: 6 March 2019

Published: 17 March 2019

Publishing services provided by Knowledge

(c) B.L. Demin et al. This article is distributed under the terms of the Creative Commons

Attribution License, which permits unrestricted use and redistribution provided that the original author and source are credited.

Selection and Peer-review under the responsibility of the NIOKR-2018 Conference Committee. technological properties and uses.

Keywords: disintegrating slags, stabilization, micro additives, rotor-type installation

\section{Introduction}

Over $50 \%$ of ferroalloy production slags are susceptible to silicate is integration in process of cooling. Most of them are refinery ferrochrome slags. Subjected to disintegration are also slags of silicocalcium, metal manganese and certain addition alloys, slags from "furnace-ladle" steelmaking installations, high-basic slags of certain steelmaking productions, etc. Disintegration products are predominantly fine-grain finely dispersed pulverous material which, until it gets caked, is easily aerated and contaminates atmospheric air, soil, water bodies, etc. The disintegration is caused by polymorphous conversions of dicalcium silicate which are accompanied by increase of the specific volume by $10-12 \%$ in course of its transiting from $-\beta$ to $-\gamma$ form. Over $80 \%$ of disintegrating slags have particle sizes under $100 \mu \mathrm{m}$, of them over $40 \%$ of particles are smaller than $50 \mu \mathrm{m}$. The basic mineral of disintegrated slag is the low-temperature ' $\gamma$ form of dicalcium silicate. Within the slag, larnite (the $\beta$ form of dicalcium silicate), periclase, spinel and chromite are also crystallized. Presence of chrome compounds (chromite and chromates) in the slag composition amplifies the negative effect of high-dispersed reaction material on 
the environment. Stabilization of slag ensures a real decrease of the damage brought to the ecological system by slag disintegration products. In process of storage, due to the effect of atmospheric moisture, partial carbonization of lime occurs in waste pile covering layers, and the disintegration products are agglomerated into dense crusts. Accumulations of disintegration products in waste piles of ferroalloy plants may reach dozens of million tons, and their further increasing is a real threat to the environment and population (Figure 1).

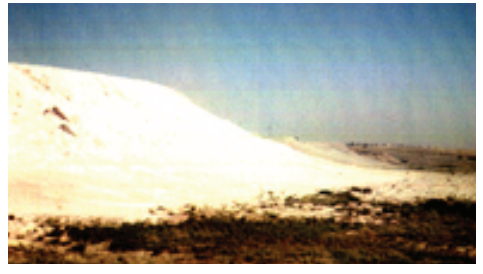

a

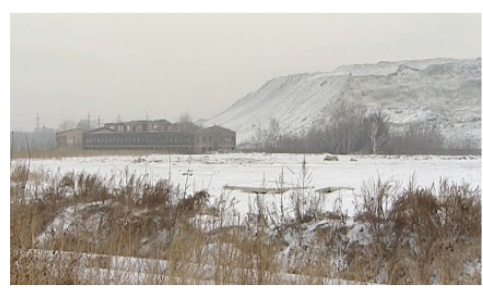

b

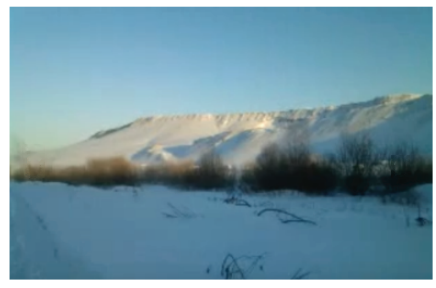

C

Figure 1: Waste piles of refined ferrochrome slags of: $a$ - Aktyubinsk Ferroalloy Plant; $b$ - Serov Ferroalloy Plant; c - Chelyabinsk Electro-Metallurgical Integrated Works.

Stabilization of slag ensures a real decrease of the damage brought to the ecological system by slag disintegration products. So, problems of prevention of silicate disintegration of slags are paid much attention in recent years.

Chemical stabilization of slag in existing metallurgical processes is unfeasible in economic terms, as it requires larger additions of stabilizers for significant alteration of the slag chemical composition. Moreover, significant alteration of applied compositions is often unacceptable for a technological process.

That is why problems of prevention of silicate disintegration of slags by crystalchemical and thermal methods are paid much attention in recent years. At Aktyubinsk Ferroalloy Plant, personnel of Ural Institute of Metals elaborated the technology of crystal-chemical stabilization of refined ferrochrome slags by means of feeding of boron compounds micro additions into a furnace [1]. As a boron-containing addition, borate ore of Indersky deposit was primarily used, then calcium boart received from datolite ore of Dalnegorsk deposit, and at last colemanite - a natural mineral of Kestelek deposit (Turkey). The basic new property of refined ferrochrome slags acquired in result of stabilization is stability of the structure. In course of cooling, further storage and use, slag does not practically undergo any polymorphous conversions, does not change volume of the crystalline lattice and does not fall to powder. After cooling down, it holds the form and dimensions of a reservoir it was drained into. Non-stabilized slag will fall into powder in process of cooling and storing. Thanks to stabilization, the slag not just changes its physical state - instead of a fine-grain finely dispersed material, a 
lumpy non-dusty sparsely soluble material is acquired - but in process of stabilization its mineral composition is modified as well (Figure 2).

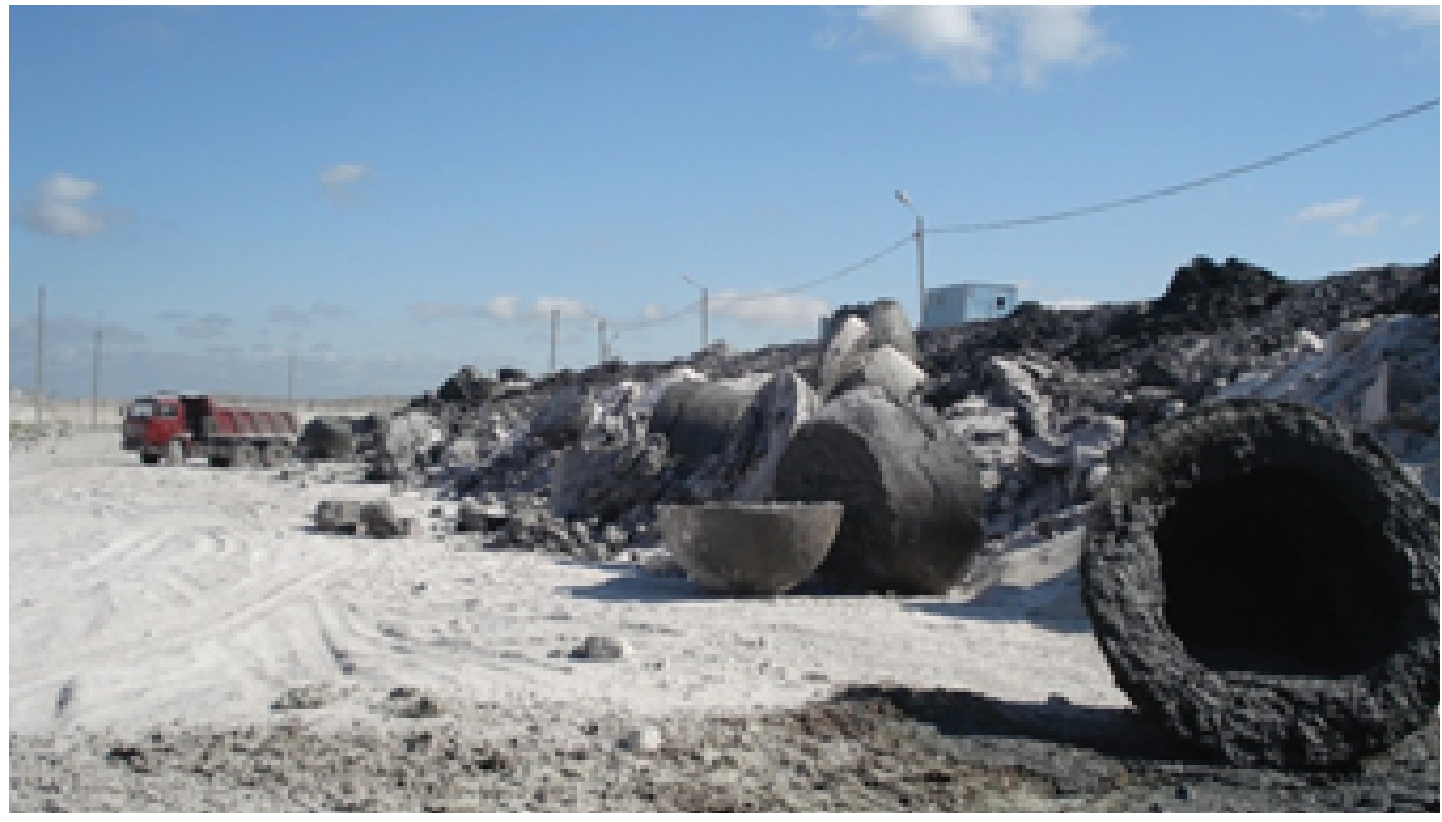

Figure 2: A view of disintegrating slag upon crystal-chemical stabilization.

The basic mineral of the slag becomes belite - $\beta$ dicalcium silicate, a hydraulically active mineral which, when interacting with water, demonstrates binding properties and may become a base for cement production. Presence of belite in the slag composition makes a positive effect also on construction properties of the stabilized slag. Crushed stone, sand and gravel-sand mixtures received after crushing and sorting of stabilized slag will better interact with mortar of cement and thus improve the concrete grade and strength of concrete structures. Upon acquiring a number of new consumer properties the stabilized slag becomes a base for production of mass use products, so it will not get accumulated in waste heaps and create bad ecological situation in the region. Prevention of disintegration allowed to handle the stabilized slag of refined ferrochrome in the same way as any stable lumped slag, i.e. to crush, to sort and to enrich it (remove metallic inclusions) according to modern technologies. Introduction of boron compound in a heat allowed to reduce viscosity and temperature of slag and metal melts in the reaction zone of refinery furnaces, to achieve completeness of passing of the chrome oxides reduction reactions, to improve the metal yield, and due to new technologies of hydraulic skimping and magnetic separation on poly-gradient magnetic separators to minimize losses of metal with slags. The technology of crystal-chemical stabilization of slags from the refined ferrochrome production was approbated at Serov Ferroalloy Plant and Chelyabinsk Electro-Metallurgical Integrated Works [2]. 
Modern technologies of post-melting refining of steel are often accompanied by generation of refinery slags which are also susceptible to silicate disintegration. Application of the technology of crystal-chemical slag stabilization in a steelmaking process allowed to prevent disintegration of refinery slags and receive lumped material with predominance of the active belite form of dicalcium silicate [3]. The slag acquires a number of new process properties allowing to remove metal inclusions from it, use it instead of lime in production of grey iron, steel, active crushed stone and gravel-sand mixtures in road construction, in production of cement, dry hardening mixtures, filtering materials, sorbents, etc. Use of slag instead of lime in the steelmaking process alone will result in saving about 2000 rubles per one ton of slag used [4]. A weak point of the crystalchemical method of disintegrating slag stabilization is use of the relatively expensive boron-containing material.

One more method of prevention of silicate disintegration which found its practical use is the thermal method whereat crystallization is retarded by shock cooling (quenching) of the slag melt; stabilization is achieved due to lack of time for intra-crystalline changes [5]. It is widely used in the process for granulated slag production. In recent times the technology of liquid slag processing in drum-type aggregates begins to be used wherein destruction of the jet and melt cooling is realized on moving metal bodies located into a kiln bar drum cavity [6]. The technology has been tested on practically all slags and is especially interesting for stabilization of refinery self-disintegrating slags, including those from "ladle-furnace" installations [7, 8]. Refined ferrochrome slags were processed in an experimental drum-type installation in conditions of Shop 2 of Aktyubinsk Ferroalloy Plant. The slag was removed from the drum by means of a slat-type conveyor. The temperature of the refined ferrochrome slag at the furnace outlet is $1650-1720{ }^{\circ} \mathrm{C}$. To cool down metal bodies, installation elements and slag melt, water was fed in amount of $0,4-0,6 \mathrm{~m}^{3}$ per one ton of the melt. At the output of the installation, slag was received with coarseness 0-10 mm, with a stable structure YC1-YC2 per GOST 3344-83.

The advantage of the thermal method of slag stabilization is manifested in reducing of routine costs, payments for electric power and water.

The drum- (rotor-) type installation was used for reprocessing of liquid slags from ferro silicomanganese in conditions of West-Siberian Electro-Metallurgical Plant, Figure 3. See Figures 4, 5 where the moment of feeding of the slag melt into the installation and discharging of the cooled slag into a receiving reservoir is shown.

Laboratory studies and industrial tests of the crystal-chemical and thermal stabilization of ferroalloy and steelmaking slags in "furnace-ladle" installations showed the technical, economic and ecologic feasibility of their use. 


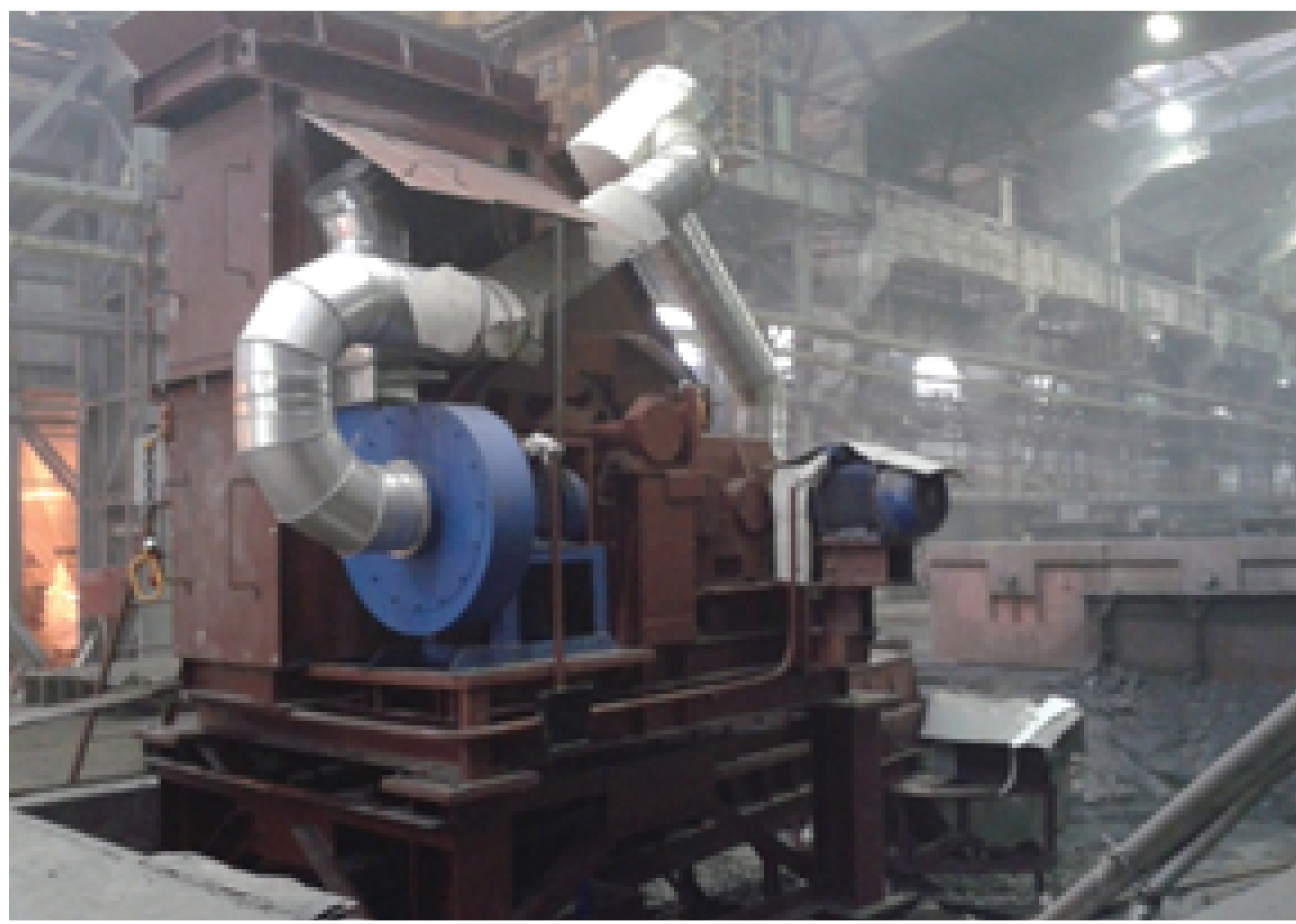

Figure 3: Allocation of the rotor-type installation in the receiving trench for slag of West-Siberian ElectroMetallurgical Plant.

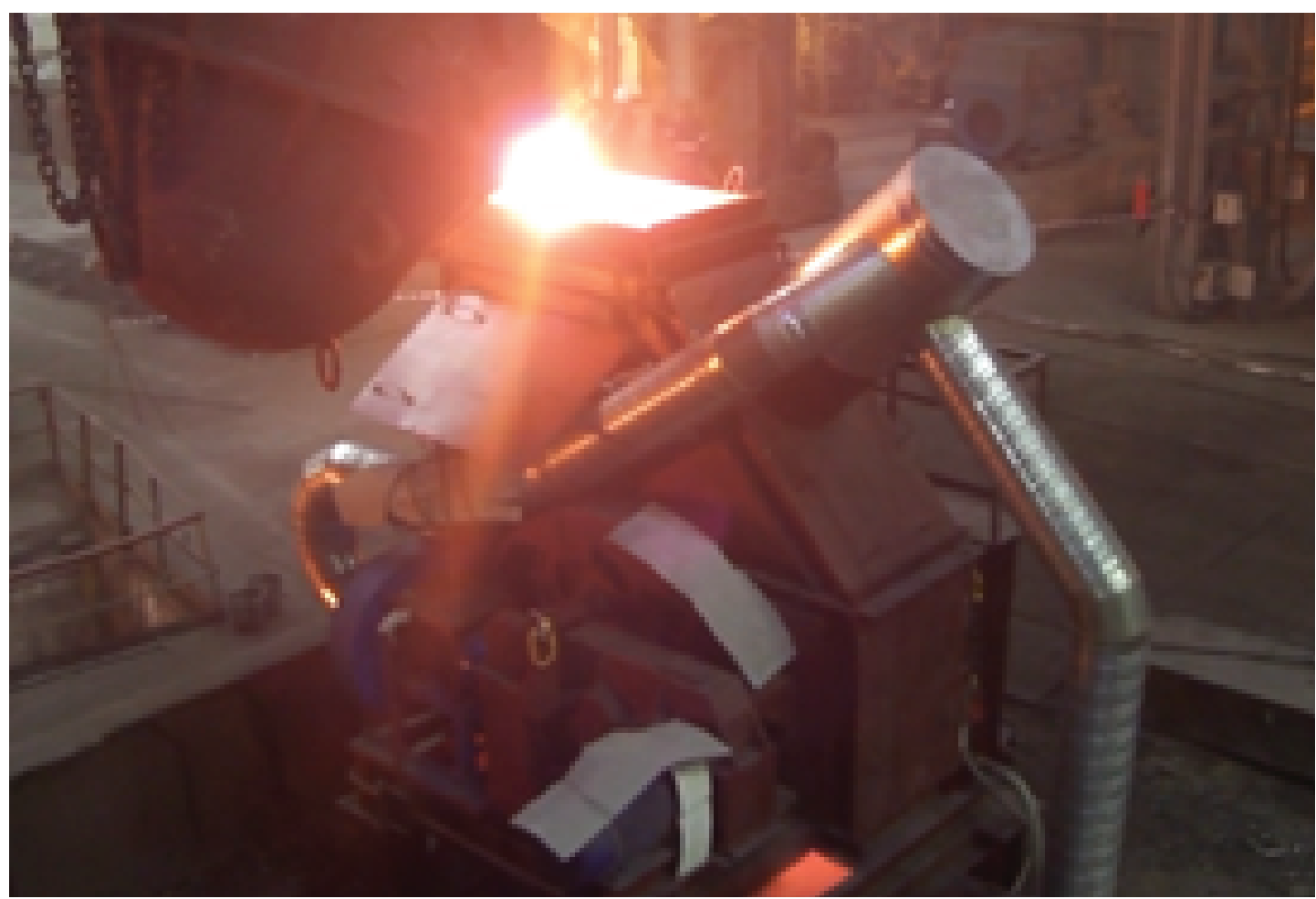

Figure 4: Feeding of slag melt into the installation. 


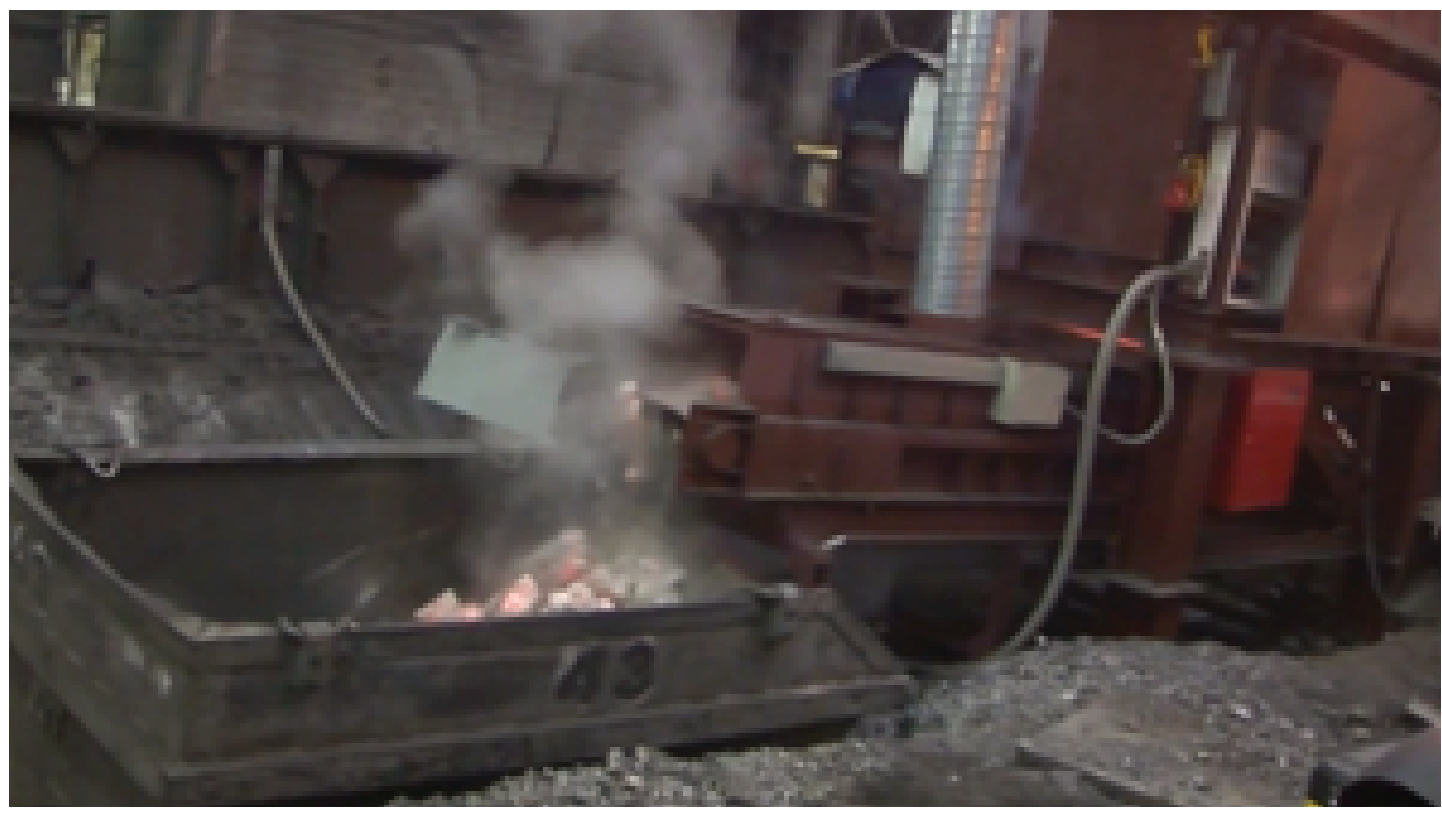

Figure 5: Discharging of cooled slag from the installation into the receiving reservoir.

\section{References}

[1] Grabeklis A.A., Demin B.L., Kayrakbayev S.N. et al. (2010). The new in the technology of crystal-chemical stabilization of slags from refined ferrochrome production //Stal No. 5, p. $78-83$.

[2] Smirnov L.A., Grabeklis A.A., Demin L.B. (2009). The modern state of reprocessing of ferroalloy production slags, Stal. - No. 1. - p. 86-89.

[3] B.L. Demin, Yu.V. Sorokin, R.Ya. Sharafutdinov, A.V. Murzin, A.M. Zhilin. Approbation of the technology of crystal-chemical stabilization of self-disintegrating steelmaking slags.

[4] Sorokin Yu.V., Demin B.L., Shcherbakov Ye.N. (2017). Efficiency of recycling of slags from "furnace-ladle" installation in electric furnaces. Bulletin of scientific-technical and economic information. Chernaya Metallurgiya (Ferrous Metallurgy). No. 10,.

[5] V.S. Gorshkov, S.Ye. Aleksandrov, S.I. Ivashchenko et al. (1985). Complex recycling and use of metallurgical slags in civil engineering. Moscow, Stroyizdat, 272 p.

[6] Demin B.L., Sorokin Yu.V., Shchetbakov Ye.N. et al. (2016). Perspectives of application of drum-type installations for reprocessing of metallurgical slags. Metallurg Journal No. 11.

[7] Smirnov L.A., Sorokin Yu.V., Demin B.L., Myasnik A.A. (2008). Technological devices for reprocessing of slags in liquid state. Chernaya Metallurgiya (Ferrous Metallurgy). No. 1303. p. 47-51. 
[8] Sorokin Yu.V., Demin B.L., Smirnov L.A. et al. (2012). Reprocessing of MSP slags in an experimental drum-type installation with a ball piece. Stal.. No. 3. p. $70-73$. 